\title{
The Association between Excessive Daytime Sleepiness and Blood Pressure in Patients with Obstructive Sleep Apnea-Hypopnea Syndrome
}

\author{
Cheon-Sik Kim ${ }^{1}$, Dae-Sik Kim ${ }^{2}$ \\ ${ }^{1}$ Departments of Neurology, Asan Medical Center, Seoul 05505, Korea \\ ${ }^{2}$ Department of Clinical Laboratory Science, Dongnam University, Suwon 16328, Korea
}

\section{폐쇄성 수면 무호흡-저호흡증후군 환자에서 과도한 주간졸음증과 혈압 사이의 연관성}

\author{
김천식 ${ }^{1}$, 김대식 ${ }^{2}$ \\ ${ }^{1}$ 서울아산병원 신경과, ${ }^{2}$ 동남보건대학 임상병리과
}

\begin{abstract}
The purpose of this study was to investigate the relationship between excessive daytime sleepiness (EDS) and blood pressure (BP) in patients with obstructive sleep apnea-hypopnea (OSAH). Patients were classified into four groups based on their severity of polysomnographic data: the snoring group ( $n=108)$-characterized by Apnea-Hypopnea Index $(\mathrm{AHI}<5)$; the mild OSA group ( $n=186)$ - AHI $5 \leq \mathrm{AHI}<15$; the moderate OSA group ( $n=179)-\mathrm{AHI} 15 \leq \mathrm{AHI}<30$; and the severe OSA group ( $n=233)-A H I \geq 30$. On the same night of polysomnography (PSG), BP levels were measured before sleeping (bedtime BP) and immediately after waking up on the following morning (morning BP). EDS was recognized as ESS (epworth sleepiness scale) $\geq 9$. The differences and correlations between BP and PSG parameters in the EDS and non-EDS groups of OSAH patients were analyzed. MAP was positively correlated with BMI, AHI, and total arousal $(r=0.099, r=0.142$, $r=0.135, p<0.01, p<0.01, p<0.01)$, while negatively correlated with mean $\mathrm{SaO}_{2}(r=-0.258, p<$ $0.01)$. The EDS group had overall younger population ( $47.2 \pm 11.3$ vs $50.3 \pm 11.4, p=0.023$ ), higher DBP (both bedtime and morning, $83.1 \pm 9.7$ vs $81.4 \pm 8.8$ and $86.4 \pm 9.2$ vs $83.6 \pm 9.7)(p=0.031$, $p=0.047$ ), and higher SBP (both bedtime and morning, $126.7 \pm 11.2$ vs $123.4 \pm 12.4,128.9 \pm 12.4$ vs $125.3 \pm 12.9)(p=0.021, p=0.021)$ than compared with the non-EDS group. In hypertensive OSAH patients, patients with EDS were also younger and had higher total arousal number, as well as higher morning and bedtime DBP and SBP than compared with the non-EDS group $(p<0.005$, $p=0.008, p<0.001$ and $p<0.001$ ). EDS in OSAHS patients is a special phenotype characterized by younger age, higher DBP, more severe desaturation, and hypertension.
\end{abstract}

Key words: Excessive daytime sleepiness, Obstructive sleep apnea hypopnea, Epworth sleepiness scale, Blood pressure

This is an Open Access article distributed under the terms of the Creative Commons Attribution Non-Commercial License (http://creativecommons.org/licenses/by-nc/4.0) which permits unrestricted non-commercial use, distribution, and reproduction in any medium, provided the original work is properly cited.

Copyright ( 2016 The Korean Society for Clinical Laboratory Science. All rights reserved.
Corresponding author: Cheon-Sik Kim Departments of Neurology, Asan Medical Center, 88, Olympic-ro 43-gil, Songpa-gu, Seoul 05505, Korea Tel: 82-2-3010-4997 Fax: 82-2-3010-6819 E-mail:dpel-kcs@daum.net

Received: April 25, 2016 Revised 1 $1^{\text {st: }}$ May 12, 2016 Revised $2^{\text {nd. }}:$ May 17, 2016 Revised 3 ${ }^{\text {rd: }}$ May 20, 2016 Revised $4^{\text {th }}$ : June 2, 2016 Revised $5^{\text {th: }}$ : June 14, 2016 Revised $6^{\text {th }}$ : June 30, 2016 Accepted: July 1, 2016 


\section{서 론}

폐쇄성수면무호흡-저호흡(obstructive sleep apnea-hypopnea) 은상기도의 폐쇄로 인하여 10초 이상 호흡이 멈추거나 비정상적으 로 감소된 상태를 말하며, 이는 성인의 $10 \sim 15 \%$ 에서 관찰되는 매 우 흔한 질병이며[1,2], 이는 수면 중 잦은 각성과 저산소혈증 (hypoxemia)을 발생시키고, 낮 동안의 과도한 주간졸음증 (exessive daytime sleepiness), 당뇨, 고혈압 및 뇌졸중 같은 심혈 관 질환의 유병률을 증가시킨다. 수면무호흡-저호흡을 가지고 있 는 환자 중 낮 동안 과도한 주간졸음증은 성인남자 $3 \sim 7 \%$, 성인여 자 2 5\%에서 동반되며, 비만환자와 노인연령에서 빈도가 더 높은 것으로 보고되고 있다[3,4].

폐쇄성수면무호흡-저호흡 환자는 주간졸음증을 동반한 그룹과 주간졸음증을 동반하지 않은 그룹으로 나눌 수 있는데, 과도한 주 간졸음증을 동반한 그룹은 지속적 양압 치료 후 혈압을 낮추는 효 과가 나타났으나, 주간졸음증을 동반하지 않은 그룹은 지속적인 양 압기 치료 후에도 24시간 혈압이 저하되지 않았고[5,6], 고혈압을 동반한 환자가 증가되어 있는 것으로 보고하고 있다[7].

폐쇄성수면무호흡-저호흡증후군 환자에서 과도한 주간졸음증 이 동반된 그룹은 그렇지 않은 그룹과 비교하였을 때, 특별한 표현 형이 존재할 것으로 가정하였다.

따라서 본 연구에서는 과도한 주간졸음증을 동반한 폐쇄성수면 무호흡-저호흡 환자들의 임상적 특징, 혈압의 변화, 수면다원검사 의 파라미터 변화 및 주간졸음증과 혈압 사이의 상관관계를 알아보 고자 하였다.

\section{대상 및 방법}

\section{1. 연구대상}

2013년 1월부터 12월까지 A병원 수면다원검실에 내원한 950 명 중 25세 이하 40명, 주간졸음설문지(epworth sleepiness scale, $\mathrm{ESS}$ 미작성자 35명, 수면다원검사 전 - 후 혈압 미 측정자 5명, 위식도 역류성질환(gastroesophageal reflux disease, GERD) 29명, 불면증 8 명, 파킨슨질환 10 명, 뇌졸중 7 명, 심장질환 10 명, 렘행동 수면장애환자-REM sleep behavior disorder, RBD) 61명, 사지불 안증후군(restless leg syndrome, RLS) 20명, catathrenia 3명, 체 인스톡 호흡질환 2명, 고유척수신경반응(propriospinal reflex) 2 명, 천명(stridor) 5명, 기타질환 7명을 제외시킨 706명을 연구대상 으로 하였다. 이 중 단순한 코골이만 있는 환자는 108 명, 경도의 무 호흡-저호흡 환자는 186 명, 중등도 무호흡-저호흡 환자는 179 명, 중증 무호흡-저호흡 환자는 233명 이었다.

\section{2. 연구방법}

\section{1) 주간졸음증 설문지}

야간수면다원검사를 시행하기 전 모든 환자들은 수면 중 호흡방 해설문지 및 주간졸음설문지를 작성하였다[8,9]. 주간졸음설문지 는 낮 동안 서로 다른 상황에서 졸음 가능 정도를 평가하는 설문지 로 8개의 항목으로 구성되어 있다. 각 항목은 (1) 앉아서 잡지나 신 문을 읽을 때 (2) 텔레비전 볼 때 (3) 극장이나 모임 등 공공장소에서 가만히 앉아 있을 때 (4) 한 시간 이상 운전 중인 차 안에서 가만히 앉아 있을 때 (5) 오후에 누워서 쉬고 있을 때 (6) 앉아서 상대방과 대화할 때 (7) 점심식사후 가만히 앉아 있을 때 (8) 운전 중 교통체중 으로 가만히 정지해 있을 때로 구분하였다. 점수는 '졸음증상이 전 여 없다'는 0점, '약간 있다'는 1점, '보통이다'는 2점, '대부분이다' 는 3점으로 채점하였다. 채점 점수 중 9점 이상이면 낮 동안의 과도 한 주간졸음증(excessive daytime sleepiness, EDS)이 있는 군으 로 구분하였고, 0 8점은 주간졸음증이 없는 군으로 구분하였다 (non-EDS)[10].

\section{2) 야간수면다원검사 및 파라미터}

모든 환자들은 야간수면다원검사를 시행하였다. 검사 전에 호흡 방해 수면설문지, 주간졸음증설문지 및 환자의 신체지수를 측정하 였다. 수면다원검사는 RemLogic version 2.0 기기(Embla system Inc., Broomfield, USA)를 사용하여 시행하였다. 무호흡 측정을 위 한 호흡센서로 숨을 들이쉴 때와 내쉴 때의 온도 차이를 감지하여 전기적 저항으로 변환하여 기록하는 온도감지센서(thermistor)와 저호흡 및 호흡사건과 관련된 각성 측정을 위해 비강공기압센서 (nasal pressure)를 동시에 사용하였고, 호흡에 따른 흥·복부의 움직임을 관찰하기 위해 흥부 및 복부에 호흡벨트(zRIP)를 착용하 였다. 수면단계 및 각성상태 판독을 위해 6 개 채널의 뇌파 $\left(\mathrm{F}_{3}, \mathrm{~F}_{4}\right.$, $\mathrm{C}_{3}, \mathrm{C}_{4}, \mathrm{O}_{1}, \mathrm{O}_{2}$ )를 부착하였고, 렘수면 단계 측정 시 중요한 판단기 준이 되는 3 개 채널의 턱밑 근전도, 각성과 렘수면을 구별하기 위해 2개 채널의 안전도를 미국수면의학에서 제시한 부위에 부착하였 다[11]. 우측어깨와 좌측 4 5번 늑골 부위에 1개 채널의 심전도, 주기적 사지운동이나 사지불안증후군 측정을 위해 좌·우 앞 정강 근육에 2 개의 하지 근전도, 산소포화도를 측정하기 위해 손가락에 산소포화도센서, 마이크로폰과 데시벨을 이용한 코골이 측정 및 수 면 중 환자의 수면위치를 확인할 수 있는 자세위치센서(body position sensor) 등을 동시에 기록하였다.

3) 무호흡과 저호흡 및 각성 판독

야간수면다원검사 및 판독은 미국수면학회 판독면허(registered 
polysomnography technologist, RPSGT)를 가지고 있는 숙련된 임상병리사가 담당하였다. 무호흡의 정의는 2007년 미국수면의학 회 권장기준인 온도감지센서에서 최소 10 초 이상 공기의 흐름이 $90 \%$ 이상 감소된 경우, 저호흡은 비강공기압센서에서 최소 10 초 이상 호흡량이 $30 \%$ 이상 감소하고 동시에 $4 \%$ 이상 혈중산소포화도 가 감소된 경우로 정의하였다[11].

무호흡-저호흡지수에 의한 질환의 심각도는 다음과 같이 4 그룹 으로 분류하였다. 무호흡-저호흡지수가 5미만인 그룹은 코골이 그 룹, $5 \sim 15$ 사이는 경도 무호흡 그룹, $15 ~ 30$ 사이는 중증도 무호흡 그룹, 30 이상인 그룹은 중증 무호흡 그룹으로 나누었다[11].

각성 판독은 선행하는 안정된 수면뇌파가 10 초 이상이여야 하 고, 3 초 이상 뇌파변화가 있어야하며, 렘수면에서는 턱 근전도가 1 초 이상 증가되어 있어야 수면 중 각성으로 판독하였다[11].

\section{4) 혈압 및 심박수 측정}

본 연구를 위해 수축기혈압, 이완기혈압 및 심박동수가 자동적 으로 기록되는 HEM-6111 자동전자 상완혈압기(Dalian Co, Japan)를 사용하였고, 똑바로 누운 자세로 10 분간 안정을 취한 후 3 분 간격으로 2 번 연속 측정한 후 평균값으로 평가하였다. 정상인 의 경우 손목혈압과 상완혈압의 수축기혈압과 이완기혈압 모두 $\pm 10 \mathrm{mmHg}$ 차이가 나는 것으로 알려져 있어 오차를 줄이기 위해 환자가 최대한 안정된 상태에서 측정하였다.

야간 수축기혈압(bedtime systolic blood pressure, $\mathrm{SBP}$ )과 이 완기혈압(bedtime diastolic blood pressure, DBP)은 취침 시작 직전에 3 분 간격으로 2 번, 아침 수축기혈압(morning $\mathrm{SBP}$ )과 이완 기혈압(morning $\mathrm{DBP})$ 은 수면에서 깨자마자 3 분 간격으로 측정하 였으며, 야간 평균동맥혈압(bedtime mean arterial pressure, $\mathrm{MAP}$ )과 아침 평균동맥혈압(morning $\mathrm{MAP})$ 은 다음과 같은 공식을 이용하여 계산하였다[10].

평균동맥혈압 $(\mathrm{mmHg})=$ 이완기혈압+(수축기혈압-이완기혈압)/3

고혈압의 기준은 수축기혈압 $140 \mathrm{mmHg}$ 이상 또는 이완기혈압 $90 \mathrm{mmHg}$ 또는 혈압과 관련하여 혈압약을 복용한 사람으로 정의 하였다[10,12].

\section{5) 통계분석}

통계처리는 SPSS version 21.0 (SPSS Inc., Chicago, IL, USA) 을 사용하였다. 대상자의 일반적 특징, 수면다원검사 결과와 관련 된 수면관련 변수는 기술통계를 통하여 분석하였다. 판독기준에 따 른 무호흡-저호흡지수, 목둘레, 체질량지수, 주간졸음증 및 무호흡-
저호흡지수에 따른 혈압의 변화 등은 $\mathrm{ANOVA}$ 를 사용하여 분석하 였고, 과도한 주간졸음증 군과 비주간졸음증 군의 파리미터는 독립 표본 $\mathrm{t}$ 검정(independent $\mathrm{t}$ test)으로 분석하였다.

\section{결 과}

\section{1. 대상자의 일반적 특징}

폐쇄성수면 무호흡-저호흡 환자 706명(나이 25 83세, 남자 570 명, 여자 136 명)의 평균나이는 $49.8 \pm 11.4$ 세, 체질량지수는 $25.7 \pm 3.0 \mathrm{~kg} / \mathrm{m}^{2}$, 과도한 주간졸음증 나타내는 주간졸음설문지 채점 점수는 $9.0 \pm 4.1$ 이었고, 과도한 주간졸음증을 동반한 환자는 전체 무호흡-저호흡 환자 중 $52.4 \%$ (370명)이었다. 전체 환자 중 고혈압으로 진단된 환자는 234 명(33.1\%)이였고, 이 중 주간졸음 중군 환자는 140 명(19.8\%), 비주간졸음증군 환자는 94명(13.3\%) 이였다. 고혈압으로 진단된 주간졸음증군 환자 140 명 중 81 명은 혈압약을 처방받고 있었고, 혈압약을 복용한 군과 비복용군의 야간 수축기혈압과 이완기혈압(126.2 \pm 12.8 vs $148.4 \pm 13.4,82.5 \pm 8.4$ vs 93.2 \pm 9.1$)$, 아침수축기혈압과 이완기혈압(128.7 \pm 10.2 vs $149.4 \pm 15.4,83.9 \pm 9.4$ vs 95.8 \pm 9.5$)$, 비주간졸음증군 환자 94 명 중 혈압약을 복용한 사람은 42 명이고, 혈압약을 복용한군과 비복용 군의 야간수축기혈압과 이완기혈압( $124.5 \pm 11.6$ vs $144.2 \pm 11.4$, $82.2 \pm 7.4$ vs $92.7 \pm 8.8$ ), 아침수축기혈압과 이완기혈압( $123.7 \pm 9.5$ vs $149.4 \pm 15.4,82.7 \pm 9.1$ vs 93.7 \pm 9.1 중 아침수축기 및 이완 기혈압이 혈압약을 복용한군과 비복용군에서 둘 다 높아져 있는 것 으로 나타났다.

\section{2. 무호흡-저호흡 중증도에 따른 혈압의 변화}

연구대상 706명은 수면다원검사 결과에 따른 무호흡-저호흡지 수가 5미만인 그룹은 코골이 그룹(n=108), 5 15 사이는 경도 무 호흡 그룹( $n=186), 15 \sim 30$ 사이는 중증도 무호흡 그룹( $n=179), 30$ 이상인 그룹은 중증 무호흡 그룹(n=233)으로 나누었다. 중증도에 따른 각 그룹의 나이, 목둘레, 체질량지수, 주간졸음증 수치는 무호 흡-저호흡 지수가 높을수록 모두 유의하게 증가하였으며, 야간 수 축기혈압(bedtime $\mathrm{SBP}$ )과 이완기혈압(bedtime $\mathrm{DBP}$ ), 아침 수축 기혈압(morning $\mathrm{SBP}$ )과 이완기혈압(morning $\mathrm{DBP}$ ), 야간 평균동 맥혈압(bedtime MAP)과 아침 평균동맥혈압(morning MAP)은 무 호흡-저호흡 지수가 증가할수록 혈압이 유의하게 증가되었다 (Table 1). 
Table 1. Characteristics of subjects according to AHI grading

\begin{tabular}{|c|c|c|c|c|c|}
\hline & $\begin{array}{l}\text { Snoring }(n=108) \\
\quad(\text { mean } \pm S D)\end{array}$ & $\begin{array}{l}\text { Mild }(n=186) \\
(\text { mean } \pm S D)\end{array}$ & $\begin{array}{l}\text { Moderate }(n=179) \\
\quad(\text { mean } \pm S D)\end{array}$ & $\begin{array}{l}\text { Severe }(n=233) \\
\quad(\text { mean } \pm S D)\end{array}$ & $p$-value \\
\hline Age (years) & $45.1 \pm 11.3$ & $50.1 \pm 11.3$ & $51.1 \pm 10.9$ & $50.7 \pm 11.4$ & $<0.001$ \\
\hline $\mathrm{NC}(\mathrm{cm})$ & $36.5 \pm 3.2$ & $38.2 \pm 3.4$ & $39.0 \pm 4.2$ & $40.9 \pm 3.1$ & $<0.001$ \\
\hline $\mathrm{BMI}\left(\mathrm{kg} / \mathrm{m}^{2}\right)$ & $24.0 \pm 3.0$ & $24.7 \pm 2.9$ & $25.8 \pm 3.1$ & $27.2 \pm 3.7$ & $<0.001$ \\
\hline ESS (points) & $8.1 \pm 4.7$ & $8.7 \pm 4.7$ & $9.2 \pm 5.0$ & $9.6 \pm 5.0$ & 0.036 \\
\hline AHI (events/h) & $2.1 \pm 1.4$ & $9.3 \pm 2.9$ & $22.2 \pm 4.3$ & $49.7 \pm 16.0$ & $<0.001$ \\
\hline Lowest $\mathrm{SpO}_{2}(\%)$ & $89.7 \pm 3.7$ & $85.4 \pm 4.4$ & $81.2 \pm 5.0$ & $74.4 \pm 9.5$ & $<0.001$ \\
\hline Total arousal number & $113.7 \pm 47.6$ & $130.5 \pm 46.0$ & $162.1 \pm 50.6$ & $256.3 \pm 91.6$ & $<0.001$ \\
\hline ODI (events/h) & $1.9 \pm 1.9$ & $8.4 \pm 4.5$ & $20.0 \pm 7.1$ & $46.5 \pm 16.6$ & $<0.001$ \\
\hline Bedtime SBP mmHg & $123.5 \pm 11.6$ & $125.4 \pm 10.6$ & $127.1 \pm 10.9$ & $129.8 \pm 12.9$ & $<0.001$ \\
\hline Morning SBP mmHg & $124.0 \pm 10.6$ & $126.6 \pm 10.9$ & $128.6 \pm 10.6$ & $133.8 \pm 14.6$ & $<0.001$ \\
\hline Bedtime DBP $\mathrm{mmHg}$ & $81.2 \pm 8.2$ & $81.5 \pm 9.3$ & $83.1 \pm 8.4$ & $85.8 \pm 9.7$ & $<0.001$ \\
\hline Morning DBP mmHg & $83.1 \pm 8.7$ & $84.5 \pm 8.2$ & $86.2 \pm 8.3$ & $89.8 \pm 10.4$ & $<0.001$ \\
\hline Bedtime MAP mmHg & $95.3 \pm 8.7$ & $96.1 \pm 8.9$ & $97.8 \pm 8.4$ & $100.4 \pm 9.9$ & $<0.001$ \\
\hline Morning MAP mmHg & $96.7 \pm 8.6$ & $98.6 \pm 8.4$ & $100.4 \pm 8.2$ & $104.5 \pm 10.9$ & $<0.001$ \\
\hline
\end{tabular}

${ }^{*} p$-value was calculated by ANOVA.

Abbreviation: AHI, apnea hypopnea index; SD, standard deviation; NC, neck circumference; BMI, body mass index; ESS, epworth sleepiness scale; Lowest $\mathrm{SpO}_{2}$, lowest saturation (\%), ODI, oxygen desaturation index; Bedtime SBP, bedtime systolic blood pressure; Morning SBP, morning systolic blood pressure; Bedtime DBP, bedtime diastolic blood pressure; Morning DBP, morning diastolic blood pressure, Bedtime MAP, bedtime mean arterial pressure; Morning MAP, morning mean arterial pressure.

Table 2. Demographic, polysomnographic and blood pressure pattern in OSAHS patient's with different phenotype of EDS

\begin{tabular}{lccc}
\hline & $\begin{array}{c}\text { EDS (ESS } \geq 9) \\
(n=370) \\
(m e a n \pm S D)\end{array}$ & $\begin{array}{c}\text { non-EDS (ESS<9) } \\
(\mathrm{n}=336) \\
(\text { mean } \pm \text { SD })\end{array}$ & p-value \\
\hline Age (years) & $47.2 \pm 11.3$ & $50.3 \pm 11.4$ & 0.023 \\
$\mathrm{NC}(\mathrm{cm})$ & $39.1 \pm 3.5$ & $39.0 \pm 4.0$ & 0.696 \\
$\mathrm{BMI}\left(\mathrm{kg} / \mathrm{m}^{2}\right)$ & $25.8 \pm 3.6$ & $25.6 \pm 3.3$ & 0.401 \\
ESS (points) & $13.2 \pm 3.6$ & $5.3 \pm 2.1$ & $<0.001$ \\
AHI (events/h) & $26.5 \pm 21.5$ & $23.4 \pm 20.4$ & 0.214 \\
Lowest SpO 2 (\%) & $80.6 \pm 9.3$ & $82.0 \pm 7.9$ & 0.040 \\
Total arousal number & $186.0 \pm 94.1$ & $172.3 \pm 81.6$ & 0.016 \\
ODI (events/h) & $24.0 \pm 20.6$ & $22.0 \pm 20.2$ & 0.465 \\
Bedtime SBP mmHg & $126.7 \pm 11.2$ & $123.4 \pm 12.4$ & 0.021 \\
Morning SBP mmHg & $128.9 \pm 12.4$ & $125.3 \pm 12.9$ & 0.021 \\
Bedtime DBP mmHg & $83.1 \pm 9.7$ & $81.4 \pm 8.8$ & 0.031 \\
Morning DBP mmHg & $86.4 \pm 9.2$ & $83.6 \pm 9.7$ & 0.047 \\
Bedtime MAP mmHg & $97.6 \pm 9.3$ & $95.1 \pm 9.3$ & 0.069 \\
Morning MAP mmHg & $100.6 \pm 9.4$ & $98.8 \pm 10.1$ & 0.061 \\
\hline
\end{tabular}

${ }^{*} p$-value was calculated by T-test.

Abbreviation: OSAHS, obstructive sleep apnea hypopnea syndrome; EDS, excessive daytime sleepiness; Mean \pm SD, mean standard deviation; NC, neck circumference; BMI, body mass index; AHI, apnea hypopnea index; ESS, epworth sleepiness scale; Lowest $\mathrm{SpO}_{2}$, lowest saturation (\%), ODI, oxygen desaturation index; Bedtime SBP, bedtime systolic blood pressure; Morning $\mathrm{SBP}$, morning systolic blood pressure; Bedtime DBP, bedtime diastolic blood pressure; Morning DBP, morning diastolic blood pressure, Bedtime MAP, bedtime mean arterial pressure; Morning MAP, morning mean arterial pressure.
Table 3. Demographic, polysomnographic and BP data for EDS versus non-EDS in patients with $A H I \geq 15$

\begin{tabular}{lccc}
\hline & $\begin{array}{c}\text { EDS (ESS } \geq 9) \\
(\mathrm{n}=209) \\
(\text { mean } \pm S D)\end{array}$ & $\begin{array}{c}\text { non-EDS }(\mathrm{ESS}<9) \\
(\mathrm{n}=203)\end{array}$ & $p$-value \\
& $48.4 \pm 11.4$ & $51.4 \pm 11.0$ & 0.024 \\
\hline Age (years) & $13.5 \pm 3.6$ & $5.4 \pm 2.0$ & $<0.001$ \\
ESS (points) & $38.6 \pm 18.6$ & $37.0 \pm 18.3$ & 0.675 \\
AHI (events/h) & $76.7 \pm 9.2$ & $78.0 \pm 7.7$ & 0.083 \\
Lowest $\mathrm{SpO}_{2}(\%)$ & $84.7 \pm 9.4$ & $82.5 \pm 9.1$ & 0.021 \\
Bedtime DBP mmHg & $88.5 \pm 9.3$ & $84.0 \pm 10.1$ & $<0.001$ \\
Morning DBP mmHg & 85.5 & \\
Bedtime MAP mmHg & $99.3 \pm 9.0$ & $95.4 \pm 9.7$ & 0.012 \\
Morning MAP mmHg & $102.9 \pm 9.9$ & $98.5 \pm 10.3$ & $<0.001$ \\
\hline
\end{tabular}

${ }^{*} p$-value was calculated by T-test.

Abbreviation: BP, blood pressure; EDS, excessive daytime sleepiness; Mean $\pm \mathrm{SD}$, mean standard deviation; $\mathrm{AHI}$, apnea hypopnea index; ESS, epworth sleepiness scale; Lowest $\mathrm{SpO}_{2}$, lowest saturation (\%), ODI, oxygen desaturation index; Bedtime $\mathrm{DBP}$, bedtime diastolic blood pressure; Morning DBP, morning diastolic blood pressure, Bedtime MAP, bedtime mean arterial pressure; Morning MAP, morning mean arterial pressure.

\section{3. 주간졸음증군(EDS)과 비주간졸음증군과(non-EDS)의 파라미터 비교}

야간수면다원검사에서 과도한 주간졸음증 표현형(EDS)군은 비 주간졸음증(non-EDS)군에 비하여 나이가 어리고, 수면 중 최저산 소포화도가 낮고, 수면 중 총 각성숫자는 상대적으로 높았고, 이는 유의한 결과를 보였다(Table 2). 


\section{4. 주간졸음증군(EDS)과 비주간졸음증군과(non-EDS)의 혈압변화 비교}

주간졸음증군은 비주간졸음증군에 비하여 야간 수축기혈압과 이

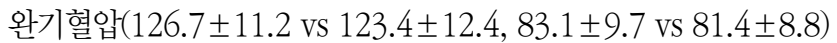

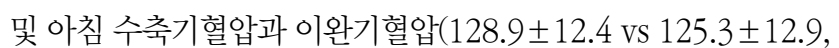

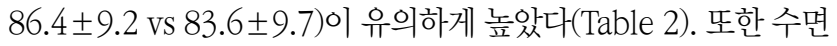
무호흡-저호흡 지수가 15 이상인 중등도 이상군에서 표현형 주간 졸음증군은 비주간졸음증군에 비하여 수축기 및 이완기혈압이 유 의하게 높은 것으로 나타났다(Table 3). 주간졸음증군에서 고혈압 군과 비고혈압군의 평균야간동맥혈압(고혈압군 VS 비고혈압군,

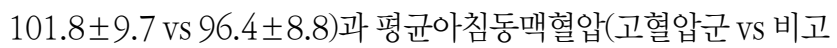

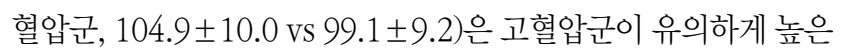
것으로 나타났다(Table 4).

\section{5. 야간수면다원검사 파라미터와 혈압과의 상관관계 분석}

수면파리미터와혈압과의 이변량상관관계에서 평균동맥혈압과 체 질량지수, 무호흡-저호흡지수, 총각성지수는양의상관관계로 나타났고 $(\mathrm{r}=0.099, \mathrm{r}=0.142, \mathrm{r}=0.135, p<0.01, p<0.01, p<0.01)$, 최저산소

A

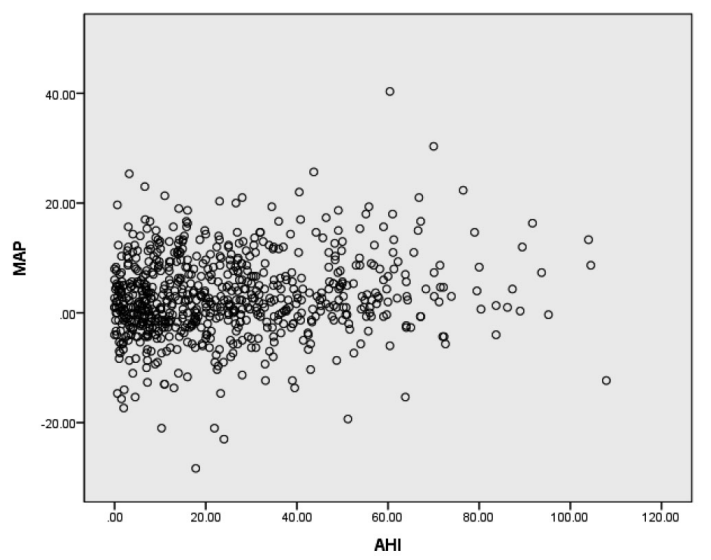

C

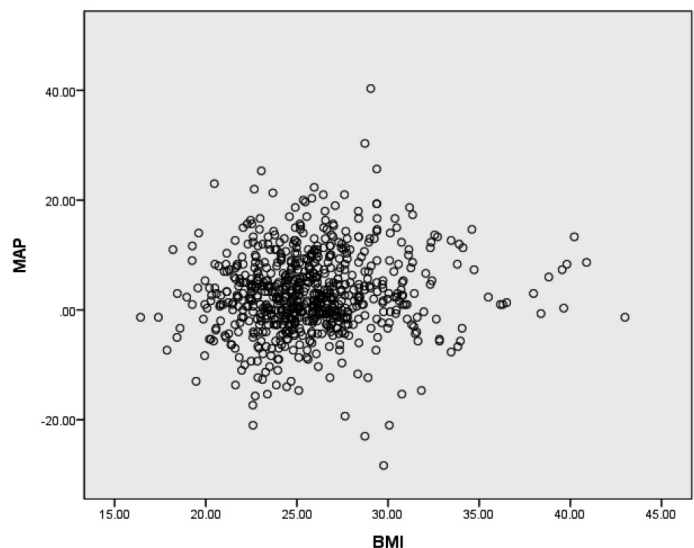

Table 4. Demographic, polysomnographic and BP data for HTN versus non-HTN in patients with EDS

\begin{tabular}{lccc}
\hline & $\begin{array}{c}\text { EDS (HTN) } \\
(\mathrm{n}=140) \\
(\text { mean } \pm \text { SD })\end{array}$ & $\begin{array}{c}\text { EDS (non-HTN) } \\
(\mathrm{n}=230) \\
(\text { mean } \pm \text { SD })\end{array}$ & $p$-value \\
\hline Age (years) & $54.8 \pm 9.2$ & $46.7 \pm 11.3$ & $<0.001$ \\
ESS (points) & $13.9 \pm 3.8$ & $12.9 \pm 3.4$ & 0.018 \\
AHI (events/h) & $31.7 \pm 23.2$ & $24.10 \pm 20.3$ & 0.004 \\
Lowest SpO $(\%)$ & $78.9 \pm 10.0$ & $81.4 \pm 8.8$ & 0.027 \\
Bedtime SBP mmHg & $132.6 \pm 12.6$ & $125.0 \pm 11.6$ & $<0.001$ \\
Morning SBP mmHg & $134.7 \pm 13.0$ & $126.8 \pm 12.2$ & $<0.001$ \\
Bedtime DBP mmHg & $85.3 \pm 8.7$ & $82.6 \pm 8.7$ & 0.008 \\
Morning DBP mmHg & $88.8 \pm 9.8$ & $85.6 \pm 9.5$ & 0.005 \\
Bedtime MAP mmHg & $101.8 \pm 9.7$ & $96.4 \pm 8.8$ & $<0.001$ \\
Morning MAP mmHg & $104.9 \pm 10.0$ & $99.1 \pm 9.2$ & $<0.001$ \\
\hline
\end{tabular}

${ }^{*} p$-value was calculated by T-test.

Abbreviation: BP, blood pressure; HTN, hypertension; EDS, excessive daytime sleepiness; Mean \pm SD, mean standard deviation; AHI, apnea hypopnea index; ESS, epworth sleepiness scale; Lowest $\mathrm{SpO}^{2}$, lowest saturation (\%), ODI, oxygen desaturation index; Bedtime DBP, bedtime diastolic blood pressure; Morning DBP, morning diastolic blood pressure, Bedtime MAP, bedtime mean arterial pressure; Morning MAP, morning mean arterial pressure.

B

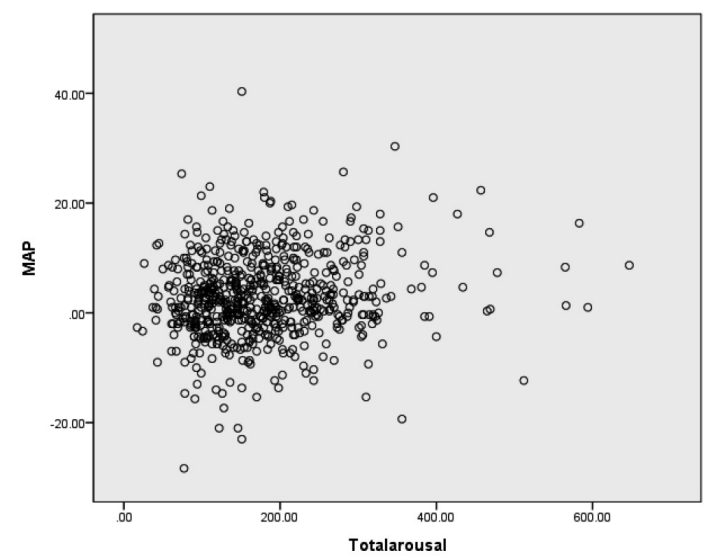

D

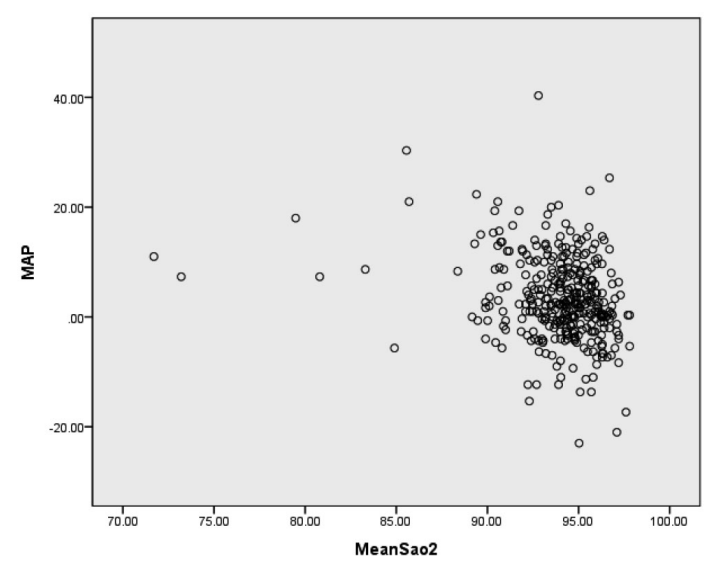

Fig. 1. Scatter plot showing relationship between MAP and (A) AHI, (B) total arousal, (C) BMI, (D) mean $\mathrm{SaO}_{2}$. 
포화도는 음의 상관관계로 나타났다(r=-0.258, $p<0.01$ ) (Fig. 1).

\section{6. 주간졸음증군(EDS)에서 고혈압에 따른 혈압변화 비교}

주간졸음증군은 비주간졸음증군에 비하여 고혈압으로 진단된 그룹의 나이가 유의하게 많았고, 수면 무호흡-저호흡지수, 수축기 및 이완기혈압이 유의하게 높았으며, 수면 중 최저산소포화도는 유 의하게 더 떨어지는 것으로 나타났다(Table 4).

\section{고 찰}

폐쇄성 수면무호흡-저호흡증후군은 수면 중 잦은 각성으로 인 해 주간졸음증의 원인이 되고, 고혈압, 심근경색 및 뇌졸중 등 혈관 질환과의 연관성이 널리 알려져 있어 임상적인 중요성이 부각되고 있다. Nieto 등[13]과 Qimin 등[10]의 보고에 의하면 과도한 주간 졸음증을 가지고 있는 폐쇄성수면 무호흡-저호흡 군은 그렇지 않 은 군과 비교하였을 때, 나이가 더 어리고, 주간 피곤함을 많이 느끼 고, 이완기혈압이 높고, 수면 중 산소 포화도가 많이 떨어지는 것으 로 보고하고 있다. 본 연구에서도 과도한 주간졸음증을 가지고 있 는 그룹이 그렇지 않은 그룹과 비교하였을 때, 상대적으로 나이가 적었고, 수면 중 최저 산소포화도가 유의하게 떨어졌고, 수면 중각 성 숫자도 유의하게 증가되는 것으로 나타났다.

김[14]과 Qimin 등[10]은 수면 무호흡-저호흡 지수가 높을수록 야간과 주간 수축기혈압 및 이완기혈압이 증가하는 것으로 보고하 였고, 본 연구에서도 수축기혈압, 이완기혈압 및 평균동맥혈압이 무호흡-저호흡지수가 증가함에 따라 유의하게 증가하는 것으로 나 타났다. 주간졸음증군과 비주간졸음증군의 야간 수축기혈압, 이완 기혈압, 주간 수축기혈압, 이완기혈압 비교하였을 때, 주간졸음증 군에서 수축기혈압 및 이완기혈압이 유의하게 증가하였다. 평균동 맥혈압은 순간적으로 측정된 혈압의 평균치를 말하며 수축기혈압 과 이완기혈압을 합하여 나눈 평균치와는 다소 차이가 나는데 그것 은 평균동맥혈압이 수축기혈압 보다는 이완기혈압과 더욱 가깝기 때문이며 실제로 평균동맥혈압의 $60 \%$ 는 이완기 혈압에 의해서 그 리고 나머지 $40 \%$ 는 수축기 혈압에 의해서 각각 결정되고 있다[15]. 특히 나이가 많아질수록 평균동맥혈압은 이완기 혈압에 더욱 가까 워지는 것으로 알려져 있는데, 본 연구에서 평균동맥혈압은 두 그 룹에서 차이를 보이지 않았다.

Punjabi 등[16]에 의하면 수면무호흡-저호흡 지수가 15 이상인 중등도 및 중증 그룹에서 주간졸음증을 가지고 있는 그룹은 나이가 더 어리고, 수면 중 최저산소포화도가 더 떨어지는 것으로 보고하 였고, 이완기 혈압, 평균 동맥혈압은 주간졸음증을 가지고 있는 그 룹이 $3 \sim 5 \mathrm{mmHg}$ 정도 높은 것으로 보고하였다. 주간졸음증을 가
지고 있는 그룹은 수면 중 잦은 각성으로 인해 낮에 졸리는 증상이 증가될 것으로 생각되며, 잦은 각성은 수면 중 심장 박동을 증가시 킬 것이고, 심방박동 증가는 결론적으로 수축기혈압 및 이완기혈압 을 증가시킬 것으로 생각된다. 본 연구에서 수면 무호흡-저호흡지 수 중등도 이상 그룹에서 주간졸음증군과 비주간졸음증군과의 주 간 및 야간 수축기혈압, 이완기혈압 및 평균 동맥혈압은 주간졸음 증군에서 2 7 $\mathrm{mmHg}$ 정도 높았으며, 이는 통계적으로 유의한 차 이를 보였고, Punjabi 등[16]의 보고와 동일한 결과를 보였다.

본 연구 결과, 주간졸음증군에서 수면무호흡-저호흡 증후군을 가지고 있으면서 고혈압으로 진단된 그룹이 나이가 더 많고, 수면 무호흡-저호흡 지수, 수축기 및 이완기혈압이 더 높았으며, 수면 중 최저산소포화도는 더 떨어져 있는 것으로 나타났다.

본 연구의 제한점은 첫째, 8 개 항목으로 구성되어 있는 주간졸음 설문지가 다중수면잠복기검사(multiple sleep latency test, MSLT)와 같이 객관적이지 않고 개인의 주관적인 평가라는 제한점 이 있다. 둘째, 집이 아닌 병원이라는 특수적 환경에서 잠을 자려고 하니 적응하기 어려운 첫째 날 밤 효과가 작용하여 수면에 영향을 미쳤을 것이라 생각된다. 셋째, 취침전과 후에 측정하는 수축기혈 압, 이완기혈압 및 심박동수가 자동적으로 기록되는 자동전자 상완 혈압기를 사용하였고, 2 번 연속 측정한 후 평균값으로 평가하였지 만 오차가 발생할 수 있을 것으로 생각된다. 넷째, 수면무호흡-저호 흡 및 주간졸음증이 고혈압과의 연관성을 확인하기 위한 교란요인 을 보정하지 못한 제한점이 있다. 향후 관련된 연구에서는 이러한 제한점을 최대한 고려한 연구가 진행되어야 할 것으로 생각된다.

\section{요 약}

수면무호흡-저호흡를 가지고 있는 환자에서 과도한 주간졸음 증의 표현형과 혈압 사이의 관계를 조사하고자 한다. 환자는 수면 다원검사 결과에 따른 무호흡-저호흡지수가 5 미만인 그룹은 코골 이 그룹(n=108), 5 15 사이는 경도 무호흡 그룹(n=186), $15 ~ 30$ 사이는 중증도 무호흡 그룹 $(\mathrm{n}=179), 30$ 이상인 그룹은 중증 무호흡 그룹 $(n=233)$ 으로 나누었다. 혈압 측정은 검사 시작 전과 후에 똑바 로 누운 자세에서 3 분 간격으로 2 회 측정 후 평균값으로 야간 혈압 과 아침 혈압을 측정하였다. 주간졸음증군과 비주간졸음증군의 수 면 파라미터와 혈압과의 상관관계를 측정하였다. 수면 파리미터와 혈압과의 이변량 상관관계에서 평균 동맥혈압과 체질량지수, 무호 흡-저호흡지수, 총 각성지수는 양의 상관관계로 나타났고(r=0.099, $\mathrm{r}=0.142, \mathrm{r}=0.135, p<0.01, p<0.01, p<0.01)$, 최저산소포화도 는 음의상관관계로 나타났다 $(\mathrm{r}=-0.258, p<0.01)$. 주간졸음증군은 비주간졸음증군에 비해 나이가 어리고(47.2 \pm 11.3 vs $50.3 \pm 11.4$, 
$p=0.023$ ), 이완기 혈압이 높고(야간 이완기혈압과 아침 이완기혈 압, 83.1 \pm 9.7 vs $81.4 \pm 8.8,86.4 \pm 9.2$ vs $83.6 \pm 9.7)(p=0.031$, $p=0.047$ ), 수축기혈압도 높았다(야간 수축기혈압, 아침 수축기혈 압, $126.7 \pm 11.2$ vs $123.4 \pm 12.4,128.9 \pm 12.4$ vs $125.3 \pm 12.9$ ) ( $p=0.021, p=0.021)$. 무호흡-저호흡를 가지고 있으면서 고혈압이 있고, 주간졸음증을 함께 가지고 있는 그룹은 그렇지 않은 그룹에 비해 나이가 어리고, 총 각성숫자가 높고, 아침과 야간 수축기 및 이 완기혈압이 높았다 $(p<0.005, p=0.008, p<0.001, p<0.001)$. 결 론적으로 주간졸음증의 표현형은 나이가 어리고, 아침 및 야간 수 축기혈압과 이완기혈압이 높고, 수면 중산소포화도가 더 떨어졌다.

\section{Acknowledgements: None}

Funding: None

Conflict of interest: None

\section{References}

1. Fogel RB, Malhotra A, Dalagiorgou G. Anatomic and physiologic predictors of apnea severity in morbidly obese subjects. Sleep. 2003;26:15-155.

2. Ferini-Strambi L, Fantini ML, Castronovo C. Epidemiology of obstructive sleep apnea syndrome. Minerva Med. 2004;95: 187-202.

3. Peppard PE, Young T, Palta M, Skatrud J. Prospective study of the association between sleep-disordered breathing and hypertension. N Engl J Med. 2000;342:1378-1384.

4. Nieto FJ, Young TB, Lind BK, Shahar E, Samet JM, Redline S, et al. Association of sleep-disordered breathing, sleep apnea, and hypertension in a large community-based study. Sleep Heart Health Study. JAMA. 2002;283:1829-1836.

5. Barbe F, Mayoralas LR, Duran J. Treatment with continuous positive airway pressure is not effective in patients with sleep apnea but no daytime sleepiness, a randomized, controlled trial. Ann Intern Med. 2001;134:1015-1023.

6. Robinson GV, Smith DM, Langford BA. Continuous positive airway pressure does not reduce blood pressure in nonsleepy hypertensive OSA patients. Eur Respir J. 2006; 27:1229-1235.

7. Kapur VK, Resnick HE, Gottlieb DJ. Sleep disordered breathing and hypertension: does self-reported sleepiness modify the association? Sleep. 2008;31:1127-1132.

8. Johns MW. A new method for measuring daytime sleepiness: The epworth sleepiness scale. Sleep. 1991;14:540-545.

9. Johns MW. Daytime sleepiness, snoring, and obstructive sleep apnea: The epworth sleepiness scale. Chest. 1993;103:30-36.

10. Qimin W, Cheng Z, Peng J, Jing Z, Liping F, Shumin W, et. al. The association between the phenotype of excessive daytime sleepiness and blood pressure in patients with obstructive sleep apnea-hypopnea syndrome. Int J Med Sci. 2014;11(7):713-720.

11. Berry RB1, Budhiraja R, Gottlieb DJ, Gozal D, Iber C, Kapur VK, et al. American academy of sleep medicine. Rules for scoring respiratory events in sleep: update of the 2007 AASM manual for the scoring of sleep and associated events. deliberations of the sleep apnea definitions task force of the american academy of sleep medicine. J Clin Sleep Med. 2012;15:597-619.

12. Phillips B. The seventh report of the joint national committee on prevention, detection, evaluation, and treatment of high blood pressure: the JNC 7 report. JAMA. 2003;290(10):1314.

13. Nieto FJ, Young TB, Lind BK, Shahar E, Samet JM, Redline S, et al. Association of sleep-disordered breathing sleep apnea and hypertension in a large community-based study. Sleep Heart Health Study. JAMA. 2000;283:1829-1836.

14. Kim CS. The association between blood pressure and obstructive sleep apnea-hypopnea syndrome. Korean J Clin Lab Sci. 2014; 46:106-110.

15. Xiao LZ, Juan W, Rong ZJ, Yin CT. Pulsatility index in combination with biomarkers or mean arterial pressure for the prediction of preeclampsia: Systematic literature review and metaanalysis. Ann Med. 2015;47:414-422.

16. Punjabi NM, O'Hearn DJ, Neubauer DN. Modeling hypersomnolence in sleep-disordered breathing. A novel approach using survival analysis. Am J Respir Crit Care Med. 1999;159: 1703-1709. 